\title{
Extensor indicis brevis Muscle: an Unusual Muscular Variant
}

\author{
Músculo Extensor Corto del Índice: Una Inusual Variación Muscular
}

${ }^{*}$ Garbelotti Junior, S.; ${ }^{* *}$ Yukio Fukuda, T.; ${ }^{* * *}$ Rodrigues Pereira, V.; ${ }^{* * * *}$ Garcia Lucareli, P. \& ${ }^{* * * * *}$ Olave, E.

GARbelotTI, JR S.; FUKUDA, Y. T.; PEREIRA, R. V.; LUCARELI, G. P. \& OLAVE, E. Extensor indicis brevis: An unusual muscular variant. Int. J. Morphol., 30(3):1071-1073, 2012.

SUMMARY: Knowledge of anatomical variations of the musculoskeletal system is important for interpreting unusual clinical presentations. We observed the presence of an abnormal extensor indicis muscle in the left hand of an adult male cadaver. In this case, the muscle comes from the ligament and over the scaphoideum and trapezoideum bones and continues after the short muscle belly; it is attached to the dorsal aponeurosis of the indicis. This muscular disposition was described in other studies which demonstrated approximately $1.0 \%$ of incidence. Clinically, this anatomical variation may be associated with pain and swelling at the back of the hand. In these cases symptoms tend to increase due to mechanical stress and can be confused with the presence of a dorsal synovial cyst. This report will help clinicians, surgeons, occupational and physical therapists formulate better clinical or surgical decisions when presented with a rare anatomical variation.

KEY WORDS: Anatomy; Hand; Muscles; Extensor indicis muscle.

\section{INTRODUCTION}

Anatomical variations of the extensor muscles of the fingers rarely can be anticipated and sometimes can be neglected when occasionally found during surgery. These anomalous muscles can be the source of different syndromes, which appear due to manual exertion during physical activities such as practiced by craftsmen and athletes (Voigth \& Breyer, 1989).

Clinically, the pain and swelling in the back of the hand can be associated to physical exertion, and these symptoms worsen with further exertion. This pain and swelling in the hand can sometimes be confused with dorsal synovial cyst (Gahhos \& Ariyan, 1983; Della Vella \& de Giovannini, 1985). The extensor indicis is still an important option for tendon transfer in chronic disability of the abductor pollicis brevis and opponens pollicis muscles (Gonzalez et al., 1996; Batra et al., 2007).

Extensor indicis comes from the deep layer which according to comparative studies is that seems to be phylogenetically unstable and inclined to considerable evolutionary changes, as can be seen from the great variation in its presentation in the different species of primates (Abu-
Hijleh, 1993). Usually extensor indicis arises from the proximal part of the distal third of the posterior surface of the ulna, medial and distal to that of extensor pollicis longus, from the neighboring interosseous membrane, and from the septum between it and extensor pollicis longus. The muscle fibers insert in a tendon that appears on the radial border of the muscle. The muscle fibers insert in the tendon almost as far as the extensor retinaculum. At this point, the tendon passes beneath to the tendon of the extensor of the little finger and enters the fourth osteofibrous tunnel deep to the lateral tendons of extensor digitorum (Tountas \& Bergman, 1993).

Thus, this muscle crosses under the retinaculum extensorum in the fourth dorsal compartment toward deeper extensor digitorum tendons and inserts itself in the dorsal aponeurosis of the indicis, and medially to the extensor digitorum muscle. The extensor indicis movements allow an independent extension of the indicis (Gonzalez et al.).

An understanding of anatomical variations of the musculoskeletal system is important when interpreting unusual clinical presentations and for diagnosing different dorsal hand masses of planned surgical tendon transfer.

* Departament of Experimental Pathophysiology - Medical School, Universidade de Sao Paulo, Brazil.

** Department of Physical Therapy - Irmandade Santa Casa de Misericórdia de São Paulo, Brazil.

*** Department of Physical Therapy - Universidade São Camilo - São Paulo, Brazil.

***** Master Program in Physical Therapy - Universidade Nove de Julho, Brazil.

****** Faculty of Medicine, Universidad de La Frontera, Chile. 


\section{CASE REPORT}

During routine dissection procedure in the laboratory, we observed the presence of an abnormal extensor indicis muscle in the left hand of an adult male cadaver preserved in formalin $(5 \%)$ of unknown age. In this particular case, the variation is presented at the beginning of the muscle, which comes from the ligament and over the dorsum of scaphoideum and trapezoideum bones, and behind a short muscle belly of $66 \mathrm{~mm}$ of length and $21 \mathrm{~mm}$ of thickness. The muscle then follows its normal path and finally inserts itself in the dorsal aponeurosis of the indicis (Figs. 1, 2).

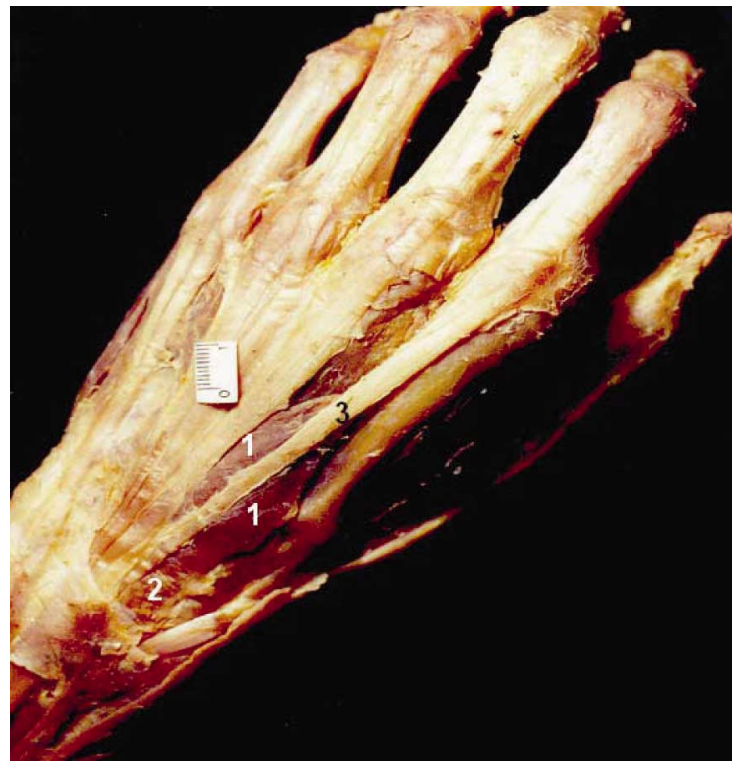

Fig. 1. Dorsal view of the wrist and hand. Extensor indicis brevis (1) with origin in the scaphoideum and trapezoideum bones (2), as well as the relationship between the muscular belly and tendons of the extensor digitorum (3).

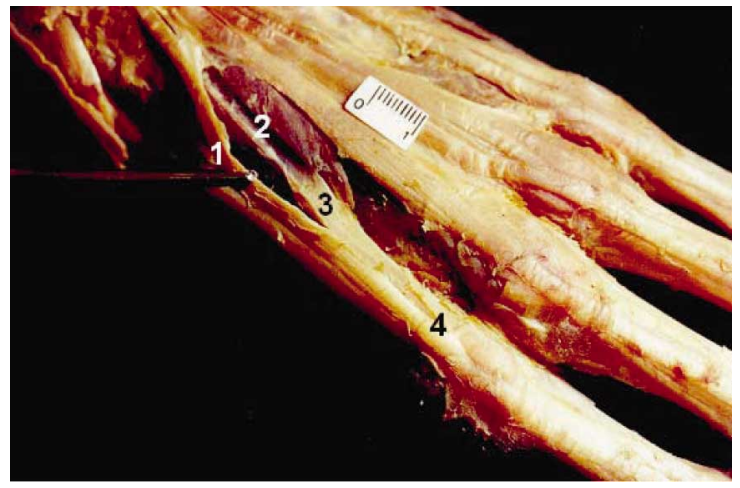

Fig. 2. Tendon of the digitorum extensor (1) demonstrating its relationship with the extensor indicis brevis (2) belly that presents an independent tendon (3) attachment moving into the anatomical dorsal aponeurosis (4) of the indicis.

\section{DISCUSSION}

Although muscle and tendon abnormalities of the hand and wrist are not uncommon, this type of variation is relatively rare. This variation was described in which the appropriate muscle was replaced in less than $1.0 \%$ of the cases studied by Voigt \& Breyer and El-Badawi et al. (1995). Our description is similar to that of Gahhos \& Aryian and Li \& Ren (2012) who referred to the extensor indicis brevis as a soft tissue originating from the ligament on the scaphoideum bone. Bingold (1964) said that the extensor indicis brevis may arise by a narrow aponeurosis from the wrist and insert by a slender tendon into the ulnar side of the extensor hood of the index. The extensor indicis muscle is widely utilized in surgeries of tendon transfer designed to restore a variety of finger movements (Gonzalez et al., Kitano et al., 1996; Batra et al.). It is utilized in reference to dysfunctions caused by functional loss of the abductor pollicis brevis, opponens pollicis muscles (Batra et al.), and extensor pollicis longus (Noorda et al.,1994). Theoretically, the preference for using the extensor indicis is in the maintenance of this function, because it receives an extensor digitorum tendon (Gonzalez et al.). Noorda et al.,did not observe pain, decreased mobility, or significant weakness in the donor finger, although he found poor finger function in $11 \%$ of the evaluated cases. On the other hand, Kitano et al. observed a functional reduction in the independent indicis extension in $26 \%$ of the cases.

The kind of muscles can be confused with a ganglion or other tumor. They often will produce symptoms as a result of exercise or overuse (Tountas \& Bergman)

The knowledge of this rare kind of anatomical variation is necessary to help diagnosis and treat the presence of pain in the back of the wrist and hand.

GARBELOTTI, JR. S.; FUKUDA, Y. T.; PEREIRA, R. V.; LUCARELI, G. P. \& OLAVE, E. Músculo extensor corto del índice: Una unusual variación muscular. Int. J. Morphol., 30(3):1071-1073, 2012.

RESUMEN: El conocimiento de las variaciones anatómicas del aparato locomotor es importante para la interpretación de las presentaciones clínicas inusuales. En este trabajo se relata la presencia de un músculo extensor indicis anormal en la mano izquierda de un cadáver de un hombre adulto, de sexo masculino. En este caso, el músculo proviene del ligamento y del dorso de los huesos escafoides y trapecio y se continúa después de un corto vientre muscular, fijándose a la aponeurosis dorsal del índice. Esta disposición muscular se ha descrito en otros estudios que demostraron aproximadamente un $1,0 \%$ de incidencia. Clínicamente, esta variación anatómica puede estar asociada con dolor e hinchazón en el dorso de la mano. En estos casos, los síntomas tienden a aumentar debido a la tensión mecánica y puede confundirse con la presencia de un quiste sinovial dorsal. Este informe ayudará a los médicos, cirujanos, terapeutas ocupacionales y físicos a tomar mejores decisiones clínicas o quirúrgicas cuando se le presenta una variación anatómica como la descrita.

PALABRAS ClAVE: Anatomía; Mano; Músculos; Músculo extensor del índice. 


\section{REFERENCES}

Abu-Hijleh, M. F. Bilateral extensor medii digiti: a rare anatomical variation. J. Hand Surg., 18A:579-82, 1993.

Batra, S.; Sakamuri, R. \& Kanvinde, R. N. Sequential traumatic bilateral extensor pollicis brevis rupture: a case report. J. Hand Surg., 32:685-7, 2007.

Bingold, A. Extensor indicis brevis. Br. J. Surg., 51:236, 1964.

Della Vella, P. \& De Giovannini, E. A case of extensor indicis brevis manus muscle. Chir. Ital., 37:214-218, 1985.

El-Badawi, M.G.; Butt, M. M.; Al-Zuhair, A. G. \& Fadel, R. A. Extensor tendons of the fingers: arrangement and variations-II. Clin. Anat., 8:391-398, 1995.

Gahhos, F. N. \& Ariyan, S. Extensor indicis brevis: a rare anatomical variation. Ann. Plast. Surg., 10:326-8, 1983.

Gonzalez, M. H.; Weinzweig, N.; Kay, T. \& Grindel, S. Anatomy of the extensor tendons to the index finger. J. Hand Surg., 21A:988-91, 1996.

Kitano, K.; Tada, K.; Shibata, T. \& Yoshida, T. Independent index extension after indicis proprius transfer: excision of juncturae tendinum. J. Hand Surg., 21A:992-6, 1996.

Li, J. \&, Ren, Z. F. Bilateral extensor indicis brevis: a rare muscular variant. Rom. J. Morphol. Embryol., 53:185-7, 2012.

Noorda, R. J. P.; Hage, J. J.; Groot, P. J. M. \& Bloem, J. J. A. M. Index finger extension and strength after extensor indicis proprius transfer. J. Hand Surg., 19A:844-9, 1994.

Tountas, Ch. \& Bergman, R. Anatomic variations of the upper extremity. New York, Churchill Livingstone Inc., 1993.

Voigt, C. \& Breyer, H. The extensor indicis brevis muscle--a rare anatomic variant. A case example and critical review of the literature. Handchir. Mikrochir. Plast. Chir., 21:276-8, 1989.
Corresponce to:

Silvio Antonio Garbelotti Junior

Rua Thomé Teixeira Vilela, 18

São Caetano do Sul

SP, Brazil

CEP: 09581-230

Phone: $(55+11) 7029-7450$

E-mail: garbelotti@terra.com.br

Received: 04-04-2012

Accepted: 26-06-2012 